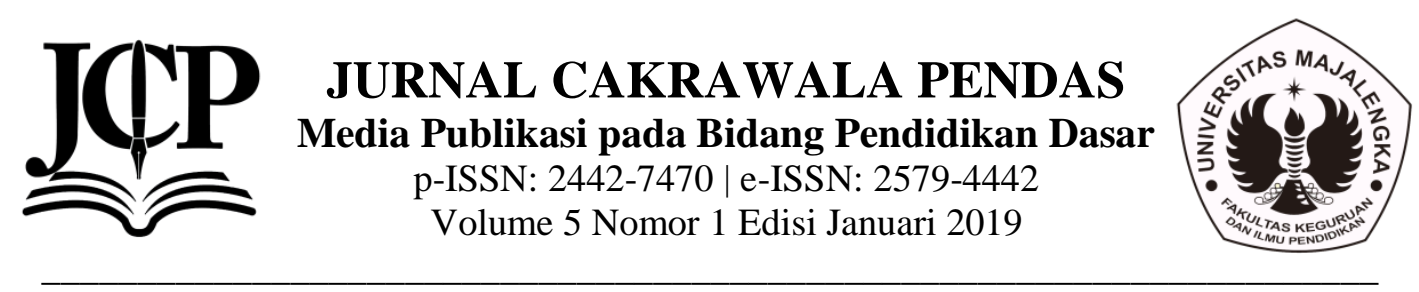

\title{
PENERAPAN MODEL MULTILITERASI UNTUK MENINGKATKAN KETERAMPILAN MENULIS KARANGAN PERSUASI PADA MATA PELAJARAN BAHASA INDONESIA DI SEKOLAH DASAR
}

\author{
Sigit Vebrianto Susilo, Budi Febriyanto, Tia Ramdiati \\ sigitvebriantosusilo@unma.ac.id \\ Universitas Majalengka
}

\begin{abstract}
ABSTRAK
Penelitian ini dilatar belakangi oleh keterampilan menulis karangan persuasi siswa yang masih rendah pada pembelajaran Bahasa Indonesia. Penelitian ini bertujuan untuk meningkatkan keterampilan menulis persuasi siswa di kelas IV SDN Jatiserang II melalui penerapan model pembelajaran multiliterasi. Penelitian ini merupakan penelitian tindakan kelas yang bekerjasama dengan guru kelas IV SDN Jatiserang II, dan jumlah siswa sebanyak 28 terdiri dari 10 siswa laki-laki dan 18 siswi perempuan. Penelitian ini berlangsung dalam tiga siklus, setiap siklus terdiri dari tiga tindakan. Alat yang digunakan dalam pengumpulan data adalah tes tertulis berupa uraian esai dan lembar observasi serta dokumentasi data yang diperoleh berupa hasil tes tertulis sebagai data primer dan hasil observasi serta dokumentasi sebagai data pendukung. Indikator keberhasilan yang ditetapkan apabila rata-rata kelas meningkat dari pratindakan, siklus I, siklus II dan siklus III. Hasil penelitian menunjukan bahwa keterampilan menulis karangan persuasi siswa mengalami peningkatan. Hal tersebut ditunjukan dengan peningkatan nilai rata-rata kelas yaitu pada akhir siklus I nilai rata-rata 63,19 dengan ketuntasan individu 9 siswa (32\%). Pada akhir siklus II nilai rata-rata 72,81 dengan ketuntasan individu 16 siswa (57\%). Selanjutnya, pada akhir siklus III nilai rata-rata 82,60 dengan ketuntasan individu 26 siswa (93\%). Selain itu dari data observasi diperoleh sebelum diberikan tindakan siswa terlihat kurang aktif dalam kegiatan pembelajaran, sebab pembelajaran lebih didominasi oleh guru. Setelah diberikan tindakan siswa terlihat aktif baik pada saat kegiatan tanya jawab maupun pada saat kegiatan publikasi hasil karya menulis. Dari hasil penelitian tersebut menunjukkan bahwa model multiliterasi dapat meningkatkan keterampilan menulis siswa.
\end{abstract}

Kata Kunci : Model Multiliterasi, Keterampilan Menulis, Bahasa Indonesia. 


\section{Pendahuluan}

Paradigma pendidikan abad ke-21 yaitu menekankan pada kemampuan siswa untuk berpikir kritis, mampu menghubungkan ilmu dengan dunia nyata dan menguasai teknologi informasi komunikasi. Pada jenjang sekolah menengah (usia 15 tahun ke atas) pemahaman membaca siswa Indonesia (selain matematika dan sains) diuji oleh sebuah Organisasi PISA untuk kerja sama dan pembangunan Ekonomi (OECD Organization for Economic Cooperation and Development). Hasil penelitian PISA tahun 2015 (dalam OECD 2016: 3) menunjukan bahwa 'siswa Indonesia berada di peringkat ke-61 dari 69 negara yang berpartisipasi dengan perolehan skor untuk Indonesia yaitu 396 (skor rata-rata OECD 496)'. Dapat dikatakan bahwa dari hasil penelitian ini praktik pendidikan yang dilaksanakan di Indonesia belum memperlihatkan fungsi sekolah sebagai organisasi pendidikan yang berupaya menjadikan semua warganya terampil membaca dan menulis untuk mendukung mereka sebagai pembelajar sepanjang hayat di era globalisasi ini.

Menurut Griffin (2012:

menyatakan bahwa Abad 21 dikenal sebagai abad pengetahuan yang merupakan landasan utama dari semua aspek kehidupan. Ada empat landasan utama yang harus dimiliki generasi abad 21 yaitu: (1) ways of thingking, (2) ways of working, (3) tools for working, (4) skills for living in the word. Keterampilan belajar yang harus dikuasai mempunyai ciri yaitu : critical thinking and problem solving. creativity and innovation, collaboration teamwork. cross-cultural understanding, communications, information and media literacy, computing and ICT literacy. Menurut Abidin (2015:55), "Pada abad ke-21 ini terdapat konsep pembelajaran literasi yang dipandang sebagai kondisi untuk lebih melek huruf, melek kata, melek makna, dan melek wacana". Konsep multiliterasi sebagai konsep penting pendidikan pada abad ke-21 dipertegas oleh Morocco, et al. (dalam Abidin 2015: 56) menyatakan bahwa 'pada abad ini yang terpenting yang harus dimiliki oleh manusia adalah kompetensi pemahaman tinggi, berpikir kritis, berkolaborasi, berkomunikasi yang difasilitasi oleh keterampilan multiliterasi'. Kompetensi berpikir artinya bahwa diharapkan sumber daya manusia hendaknya memiliki kemampuan berkomunikasi dalam rangka bekerja sama dan menyampaikan ide-ide kritis dan kreatifnya (Susilo, \& Garnisya, 2018)

UNESCO memaparkan bahwa 'literasi adalah hak setiap orang yang mendasari untuk belajar sepanjang hayat'. Maksudnya adalah bahwa kemampuan literasi dapat meningkatkan kualitas hidup individu, keluarga dan juga masyarakat. Sebab, literasi bersifat 'Multiple Effect' yang dapat memberikan efek untuk unsur yang luas sebagai contoh, kemampuan literasi dapat memberantas kemiskinan, mengurangi angka kematian anak, pertumbuhan penduduk, membantu pembangunan berkelanjutan dan terwujudnya perdamaian.

Melihat kenyataan tersebut, Kementerian Pendidikan dan Kebudayaan Indonesia mengembangkan suatu inovasi dalam dunia pendidikan Indonesia yaitu dengan adanya gerakan literasi sekolah (GLS) yang dikembangkan berdasarkan pada sembilan agenda prioritas (Nawacita) yang terkait dengan tugas dan fungsi Kemendikbud. Lebih lanjut Waluyo (2016: 3) menyatakan bahwa Butir Nawacita nomor (5) meningkatkan kualitas hidup manusia khususnya masyarakat Indonesia; (6) meningkatkan produktivitas rakyat Indonesia dan daya saing di pasar internasional sehingga bangsa Indonesia bisa bangkit dan maju bersama bangsa Asia lainnya; (8) melakukan revolusi karakter bangsa; (9) memperteguh kebhinekaan dan memperkuat karakter sosial Indonesia.

Dalam konteks kurikulum terbaru pada pembelajaran bahasa digunakan untuk mencapai empat kompetensi utama, yaitu kompetensi religius, sosial, pengetahuan dan keterampilan. Maksudnya siswa memiliki kemampuan yang memadai untuk mempelajari berbagai jenis genre teks bahasa Indonesia dan mempunyai keterampilan untuk membuat berbagai genre teks bahasa Indonesia. menurut Waluyo dkk, (2016: 1), bahwa "literasi adalah kemampuan mengakses, memahami, dan menggunakan sesuatu secara cerdas melalui berbagai aktivitas, antara lain membaca, melihat, menyimak, menulis, dan berbicara". Maksudnya adalah dengan literasi dapat mempermudah seseorang untuk berinteraksi serta berkomunikasi pada berbagai konteks 
dalam kehidupan sehari-hari dengan memakai empat keterampilan berbahasa.

Menurut Abidin (2015:55), "Pada abad ke-21 ini terdapat konsep pembelajaran literasi yang dipandang sebagai kondisi untuk lebih melek huruf, melek kata, melek makna, dan melek wacana". Konsep multiliterasi sebagai konsep penting pendidikan pada abad ke-21 dipertegas oleh Morocco, et al. (2008) menyatakan bahwa "pada abad ini yang terpenting yang harus dimiliki oleh manusia adalah kompetensi pemahaman tinggi, berpikir kritis, berkolaborasi, berkomunikasi yang difasilitasi oleh keterampilan multiliterasi'.

Sejalan dengan pendapat tersebut, Abidin (2015: 174) menyatakan bahwa Pada abad 21 terdapat konsep standar pembelajaran menulis dalam standar inti pembelajaran menulis internasional dari jenjang pendidikan dasar hingga pendidikan tinggi yang harus diarahkan untuk mengembangkan tiga hal yaitu : (1) menulis narasi untuk mengembangkan pengalaman, kenyataan, imajinasi menggunakan struktur cerita detail peristiwa yang dipilih secara efektif; (2) menulis teks informatif eksplanatori untuk menguji, menyampaikan ide informasi yang kompleks secara jelas, akurat melalui seleksi, organisasi, analisis isi yang selektif; (3) menulis argumen agar dapat mendukung hasil analisis terhadap topik substantif atau teks tertentu dengan menggunakan alasan-alasan yang rasional dan bukti-bukti yang relevan.

Berdasarkan kenyataan pada abad ke21 ini kemampuan berliterasi siswa sangat berkaitan dengan tuntutan keterampilan membaca dan menulis yang berkembang pada kemampuan memahami informasi secara analitis, kritis dan reflektif. Melihat dilapangan bahwa saat ini pembelajaran di sekolah belum mampu mewujudkan hal tersebut. Dalam persaingan global sekarang ini tingkat literasi suatu bangsa berkaitan tentang kualitas pendidikan dengan membandingkan suatu bangsa dengan bangsa lainnya.

\section{Menurut Abidin}

Keterampilan menulis dalam multiliterasi harus memperhatikan beberapa hal yaitu :

1. Kegiatan menulis harus digunakan sebagai sarana memahami teks. Jadi jenis tulisan yang dapat dikembangkan siswa antara lain intisari bacaan, sinopsis, visual teks (tabel, grafik, gambar).

2. Keterampilan menulis harus digunakan untuk mengkritisi isi bacaan. Artinya tulisan hendaknya mencerminkan tanggapan kritis, respons, resensi atau jenis tulisan lainnya.

3. Tulisan yang dihasilkan hendaknya jelas sesuai dengan jenis, tujuan dan sasaran. Maka siswa harus memahami benar struktur berbagai genre tulisan, memahami tujuan proses menulis dan memahami siapa yang menjadi sasaran baca tulisannya.

Maka dapat diambil kesimpulan bahwa keterampilan menulis sebagai sarana mengekspresikan ide gagasan dalam bentuk tulisan. Isi tulisan yang dibuat siswa tentu sangat beragam sesuai dengan isi materi yang dipelajarinya. Berdasarkan kondisi ini, siswa harus mampu mengorganisasi teks sehingga mampu menulis dengan menggunakan pola pengembangan tulisan yang baik dan benar untuk setiap materi yang berbeda. Kegiatan menulis juga hendaknya didasarkan pada hasil membaca, hasil penelitian atau observasi sebagai data mentah atau bahan tulisan. Siswa juga harus memahami benar sistematika tulisan yang dikehendaki apakah laporan penelitian, catatan lapangan, tinjauan kritis atau jenis tulisan lain.

Berdasarkan konsep multiliterasi yang bermuara pada multikompetensi maka melalui pembelajaran multiliterasi, siswa tidak hanya mempunyai satu kompetensi melainkan beragam kompetensi baik kompetensi keilmuan, kompetensi berpikir, kompetensi sikap atau karakter. Sejalan dengan hal tersebut bahwa multiliterasi dan pembelajarannya merupakan jembatan nyata dalam mengembangkan siswa agar mampu hidup dan bekehidupan di abad 21. pembelajaran multiliterasi sebagai pembelajaran yang menempatkan kemampuan membaca, menulis, menyimak dan berbicara secara optimal dan efektif guna mewujudkan situasi pembelajaran yang lebih baik untuk meningkatkan kompetensi kolaboratif, komunikatif, berpikir kreatif, berpikir kritis, menganalisis, mengevaluasi informasi dari berbagai sumber dalam berbagai disiplin ilmu dan kemampuan mengkomunikasikan informasi tersebut. 
Selanjutnya, Arianti (2015: 4) berpendapat bahwa "Sejalan dengan konsep literasi kritis yang memandang sebuah teks tidak bersifat tunabudaya tetapi literasi mencakup multibudaya". Maksudnya, sebuah teks yang disusun akan sangat dipengaruhi oleh posisi penulisnya terhadap budaya tertentu. Latar belakang penulis juga merupakan salah satu unsur lain yang sangat mempengaruhi teks, baik suku, ras, agama, latar belakang pendidikan, keyakinan, pandangan politik dan filsafat yang dianutnya.

Berkaitan dengan kenyataan bahwa pembelajaran dalam konteks abad ke-21 harus dilaksanakan dengan menggunakan pendekatan ilmiah. Oleh sebab itu, salah satu komponen dalam pembelajaran multiliterasi adalah siklus belajar atau siklus pembentukan makna. Siklus ini merupakan panduan bagi keterlaksanaan pembelajaran multiliterasi di kelas. Jadi, dapat dikatakan siklus inilah yang menggambarkan tahapan-tahapan pembelajaran multiliterasi secara umum. Siklus pembelajaran multiliterasi yang digambarkan oleh Morocco (dalam Abidin, 2015: 88) sebagai berikut :

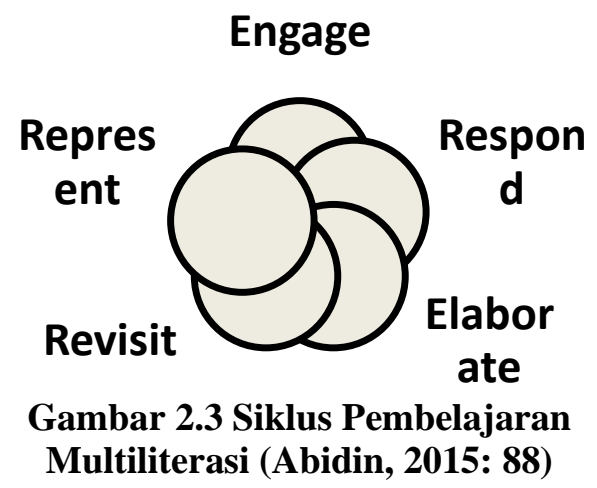

Berdasarkan gambar di atas tahapan siklus belajar dalam pembelajaran multiliterasi secara umum dapat diperinci sebagai berikut: (1) Melibatkan (Engage), (2) Merespons (Respond), (3) Elaborasi (Elaborate), (4) Meninjau Ulang (Revisit),

Mempresentasikan (Represent).

Pandangan Marocco, et al tersebut dapat dijabarkan Model pembelajaran multiliterasi merupakan perpaduan antara empat keterampilan multiliterasi dengan 10 kompetensi belajar abad ke-21. Empat keterampilan multiliterasi yang dimaksud dalam rumus di atas yaitu keterampilan membaca, menulis, berbahasa lisan atau berbicara dan ber-IT. Sedangkan kesepuluh kompetensi yang dimaksud yaitu (1) kreativitas dan inovasi, (2) berpikir kritis, pemecahan masalah dan pembuatan keputusan, (3) belajar untuk belajar, metakognisi, (4) komunikasi, (5) kolaborasi, (6) literasi informasi, (7) literasi teknologi informasi dan komunikasi (TIK), (8) sikap kewarganegaraan, baik lokal maupun global, (9) berkehidupan berkarier, (10) responsibilitas personal dan sosial, kesadaran atas kompetensi dan budaya. Oleh sebab itu, generasi muda masa depan harus mampu tidak lagi bekerja dengan otot, namun harus mampu dengan otak, mengubah paradigma bahwa bekerja tidak hanya cukup mempunyai satu kecakapan, namun multikecakapan/ multidimensional. Atas dasar ini pendidikan segianya mampu menjadi garda terdepan dalam membina dan membentuk insan muda Indonesia mempunyai kemampuan dan kecakapan multidimensional (Susilo, 2018).

\section{Metode Penelitian}

Adapun tes dalam penelitian ini dilakukan selama proses kegiatan pembelajaran berlangsung dari mulai awal hingga akhir pembelajaran pada tiap tindakannya yang bertujuan untuk mengukur keterampilan menulis siswa dengan menggunakan lembar kerja proses (LKP). Jenis tes yang diberikan adalah tes tertulis berbentuk uraian berupa tes menulis karangan persuasi menulis pengumuman. Penilaian tes ini difokuskan pada kesesuaian karangan pesuasi materi pengumuman yang dibuat siswa dengan isi gagasan yang dikemukakan, organisasi isi, gaya bahasa, ejaan dan tanda baca. Adapun, ada beberapa aspek yang dijadikan objek penilaian. Kelima aspek tersebut yaitu: (1) kesesuaian isi, (2) organisasi isi, (3) ejaan, tanda baca, (4) isi gagasan yang dikemukakan dan (5) gaya penulisan.

Metode yang akan digunakan oleh peneliti dalam melaksanakan penelitian ini adalah Penelitian Tindakan Kelas (Classroom Action Research). . Adapun tahapan tiap siklusnya yaitu mulai dari perencanaan (planning), pelaksanaan tindakan (acting), pengamatan (observing), dan refleksi (reflection). Penelitian tindakan kelas ini dirancang dengan menggunakan Model John Elliot. Adapun model yang dikemukakan John Eliot tampak lebih lengkap dan rinci. 
Dikatakan demikian karena di dalam setiap siklus dimungkinkan terdiri dari beberapa aksi yaitu antara 3-5 aksi (tindakan). Sementara itu, setiap aksi kemungkinan terdiri dari beberapa langkah karena beberapa sub pokok bahasan atau materi pelajaran yang terealisasi dalam bentuk kegiatan belajar mengajar yang terinci dan sistematis.

Peneliti menggunakan triangulasi dan expert opinion untuk menjamin dan mengembangkan validitas data. Triangulasi yaitu memeriksa kebenaran hipotesis atau analisis peneliti sendiri timbulkan dengan membandingkan dengan hasil orang lain, misalnya mitra peneliti lain, yang hadir menyaksikan situasi yang sama. Menurut Elliot (dalam Wiriatmadja, 2009: 168), 'triangulasi dilakukan berdasarkan tiga sudut pandang, yakni sudut pandang guru, sudut pandang siswa, dan sudut pandang yang melakukan pengamatan atau observasi'.

Sedangkan expert opinion menurut Wiriatmadja (2009: 171) yaitu "peneliti meminta nasihat kepada pakar", artinya yang dalam hal ini pembimbing peneliti akan memeriksa semua tahapan kegiatan penelitian peneliti dan memberikan arahan atau judgements terhadap masalah-masalah penelitian yang diteliti oleh peneliti.

Analisis data yang digunakan dalam penelitian ini adalah analisis kuantitatif dan kualitatif. Analisis data kuantitatif menggunakan teknik analisis deskriptif komparatif, yaitu membandingkan data kuantitatif dari kondisi awal, siklus I, siklus II dan siklus III. Adapun penyajian data kuantitatif di paparkan dalam bentuk presentasi dan angka. Analisis data kualitatif menggunakan berdasarkan hasil observasi aktivitas guru dan aktivitas siswa, lembar wawancara dan lembar catatan lapangan yang tujuannya untuk bahan refleksi untuk siklus I, siklus II dan siklus III.

\section{Hasil dan Pembahasan}

Dari hasil penelitian yang dilakukan peneliti sebelum melakukan tindakan, diperoleh catatan bahwa hasil keterampilan menulis siswa pembelajaran Bahasa Indonesia di Kelas IV SDN Jatiserang II Kecamatan Panyingkiran Kabupaten Majalengka masih belum efektif. Hal ini terlihat dari hasil tes keterampilan menulis karangan persuasi siswa kelas IV semester genap tahun ajaran 2016/2017 di SDN
Jatiserang II Kecamatan Panyingkiran Kabupaten Majalengka, siswa yang mencapai mastery learning sebanyak $21 \%$ atau 6 siswa, sedangkan siswa yang belum mencapai mastery learning sebanyak $79 \%$ atau 22 siswa. Sehingga dapat diketahui bahwa keterampilan menulis karangan persuasi siswa dalam materi menulis pengumuman pada pembelajaran Bahasa Indonesia masih rendah.

Belum efektifnya kegiatan belajar mengajar disebabkan karena kegiatan belajar yang digunakan oleh guru kelas IV masih bersifat konvensional, dimana pembelajaran masih berpusat pada guru. Selain itu, model pembelajaran yang digunakan dalam kegiatan belajar mengajar belum mampu untuk meningkatkan keterampilan menulis karangan persuasi siswa.

Untuk mengetahui apakah model pembelajaran multiliterasi dapat meningkatkan keterampilan menulis karangan persuasi siswa kelas IV SDN Jatiserang II Kecamatan Panyingkiran Kabupaten Majalengka, peneliti melakukan penelitian sebanyak 3 siklus dengan setiap siklus terdiri dari 3 tindakan. Setelah dilakukan tindakan pada siswa kelas IV di SDN Jatiserang II sesuai dengan rencana yang telah disusun dalam penelitian ini, ternyata keterampilan menulis karangan persuasi siswa pada pembelajaran Bahasa Indonesia menunjukkan perubahan ke arah yang lebih baik. Hasil tes keterampilan menulis karangan persuasi siswa pada kondisi awal menunjukkan bahwa siswa yang mencapai mastery learning sebanyak $21 \%$ dari 28 siswa. Hasil tes keterampilan menulis karangan persuasi siswa pada siklus I siswa yang mencapai mastery learning sebanyak $32 \%$ atau 9 orang siswa mencapai nilai di atas mastery learning, sedangkan $68 \%$ siswa atau 19 siswa memperoleh nilai di bawah mastery learning. Pada siklus II, presentase siswa yang mencapai nilai mastery learning sebanyak 55\% atau sebanyak 11 siswa memperoleh nilai mencapai mastery learning sedangkan 45\% siswa atau 9 siswa memperoleh nilai di bawah mastery learning. Sedangkan hasil tes keterampilan menulis pada siklus III, siswa yang memperoleh nilai sesuai mastery learning mencapai $43 \%$ atau 12 siswa mencapai nilai sesuai mastery learning, (14\%) 4 orang siswa mendapat nilai sesuai 
mastery learning, dan $43 \%$ siswa atau 12 siswa tidak tuntas.

Untuk mengetahui tingkat ketuntasan siswa, nilai yang diperoleh siswa dibandingkan dengan mastery learning yang telah ditentukan yaitu 75. Hasil pada siklus III sudah menunjukkan perubahan yang cukup berarti yaitu mencapai presentase 93\%. Hal ini sesuai dengan ketuntasan belajar yang telah ditetapkan oleh peneliti yaitu sebesar $75 \%$.

Dengan berakhirnya penelitian dengan tindakan siklus III, dapat dinyatakan bahwa penelitian dengan menggunakan model multiliterasi terbukti dapat meningkatkan keterampilan menulis karangan persuasi siswa pada pembelajaran Bahasa Indonesia kelas IV di SDN Jatiserang II Kecamatan Panyingkiran Kabupaten Majalengka khususnya pada materi menulis pengumuman. Dengan kata lain, hasil penelitian ini dapat menjawab rumusan masalah bahwa model pembelajaran multiliterasi dapat meningkatkan keterampilan menulis karangan persuasi siswa pada pembelajaran Bahasa Indonesia kelas IV di SDN Jatiserang II Kecamatan Panyingkiran Kabupaten Majalengka, sehingga model multiliterasi dapat dijadikan salah satu alternatif bagi guru dalam melaksanakan kegiatan belajar mengajar di kelas khususnya dalam pembelajaran Bahasa Indonesia. Secara lebih rinci, Hasil peningkatan keterampilan menulis karangan persuasi siswa pada materi menulis pengumuman peneliti sajikan dalam diagram berikut ini:

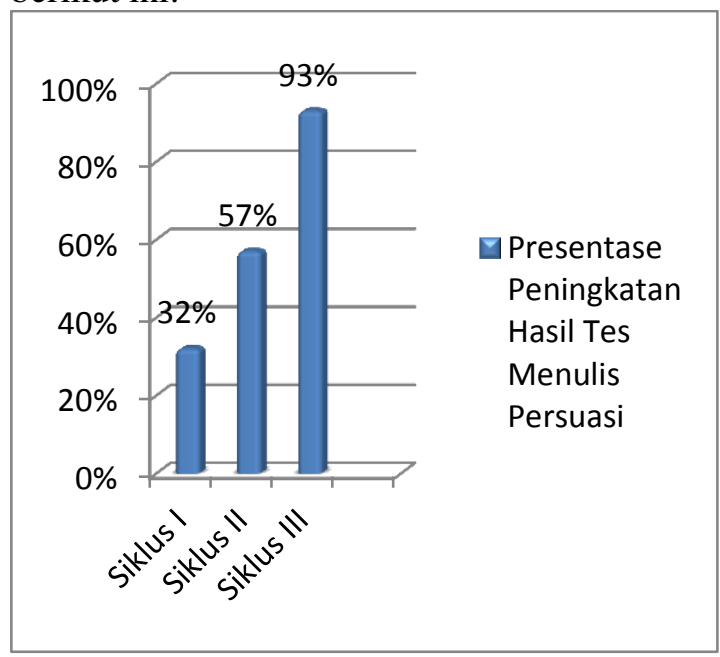

Grafik 1

Presentase Peningkatan Hasil Tes Menulis Persuasi
Adapun grafik peningkatan nilai rata-rata siswa dari siklus I sampai Siklus III dapat disajikan sebagai berikut:

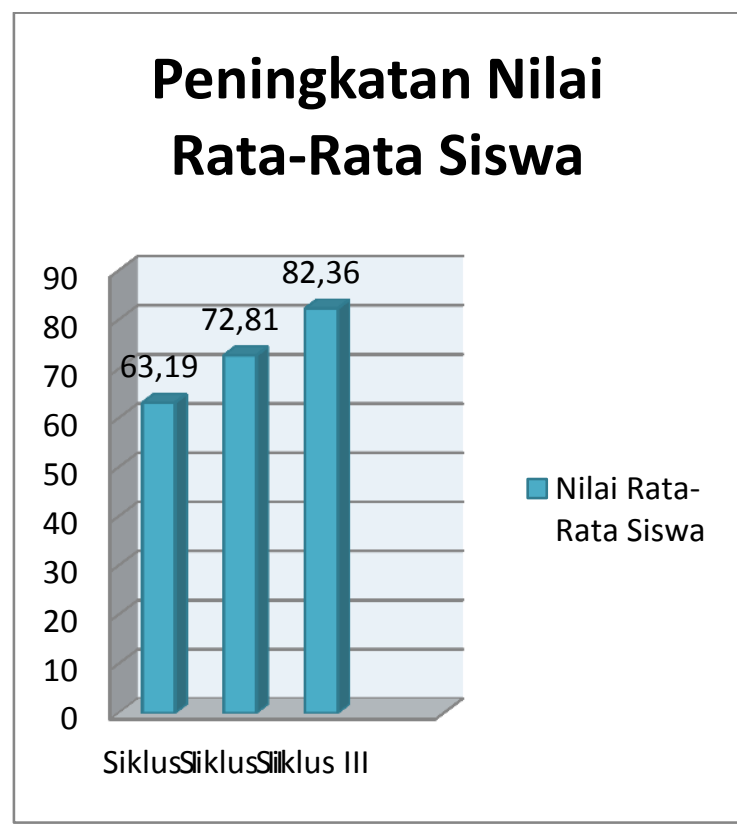

Grafik 2

Peningkatan Nilai Rata-Rata Siswa

Berdasarkan grafik 4.5 dan grafik 4.6 nilai rata-rata dan presentase ketuntasan belajar siswa dalam keterampilan menulis persuasi pada kondisi awal sampai siklus III menunjukkan adanya perubahan ke arah yang lebih baik.

Keberhasilan menggunakan model multiliterasi dalam setiap tindakan penelitian, dilaksanakan oleh peneliti dengan menggunakan media koran, majalah, surat kabar, microphone, video, untuk membantu siswa dalam pembelajaran. Keberhasilan penggunaan model multiliterasi terlihat dari hasil tes keterampilan menulis karangan persuasi siswa pada setiap tindakan yang relatif meningkat pada setiap siklusnya. Selain karena penggunaan model pembelajaran, pelaksanaan pembelajaran Bahasa Indonesia di kelas IV juga ditunjang dengan adanya media pembelajaran, keterampilan dalam mengelola kelas, memberikan arahan dan bimbingan kepada siswa, adanya penataan tempat duduk, mengajak siswa untuk mampu menyampaikan pendapat.

Penggunaan media pembelajaran dapat meningkatkan perhatian siswa. Hal ini sesuai dengan teori menurut Majid (2013: 43) bahwa "media pembelajaran berfungsi untuk 
meningkatkan perhatian siswa terhadap materi ajar". Keterampilan guru dalam mengelola kelas juga berpengaruh dalam keberhasilan pembelajaran dengan menggunakan model multiliterasi. Hal ini sesuai dengan teori yang disampaikan oleh Arikunto (dalam Susanto, 2013: 167) bahwa 'tujuan pengelolaan kelas adalah agar setiap anak di kelas dapat belajar dengan tertib sehingga tercapai tujuan pengajaran secara efektif dan efisien'. Oleh karena itu maka guru perlu memiliki keterampilan dalam mengelola kelas agar tujuan pembelajaran dapat tercapai dengan baik. Hal ini dilakukan dengan merubah posisi duduk siswa pada pelaksaan siklus II. Guru perlu memberikan arahan informasi, petunjuk, serta bimbingan kepada siswa agar terhindar dari penyimpangan, kesulitan atau kegagalan dalam melaksanakan tugas kepada siswa agar pembelajaran dapat berlangsung secara optimal.

\section{Kesimpulan}

Berdasarkan hasil penelitian, pembahasan dan hasil tindakan peneliti mengambil beberapa kesimpulan yaitu penerapan model pembelajaran multiliterasi sebagai upaya meningkatkan keterampilan menulis karangan persuasi siswa pada pembelajaran Bahasa Indonesia telah dilaksanakan dengan baik. Keberhasilan menggunakan model multiliterasi dalam setiap tindakan penelitian, dilaksanakan oleh peneliti dengan menggunakan media koran, majalah, surat kabar, microphone, video, untuk membantu siswa dalam pembelajaran.

Pembelajaran dengan menggunakan model multiliterasi ini, akan lebih baik jika guru sudah sangat memehami tentang kekurangan dan kelebihan model ini, supaya pada saat pelaksanaannya berjalan dengan baik. Sehingga pembelajaran menjadi lebih efektif dan efisien waktu. Selanjutnya dapat menerapkan model multiliterasi dengan menerapankan multikonteks, multimedia, multibudaya, multigaya belajar, dan multiintelegensi. Serta dapat meningkatkan kepekaan sosial, membangun kemampuan multiliterasi praktis baik membaca, menulis, maupun berbahasa lisan siswa dalam kehidupan sehari-hari. Serta, mampu menumbuhkan siswa untuk berpikir kritis, pemecahan masalah serta berpikir kreatif

\section{Daftar Pustaka}

Abidin, Y. (2015) Pembelajaran Multiliterasi: Sebuah Jawaban Atas Tantangan Pendidikan Abad Ke-21 Dalam Konteks KeIndonesiaan. Bandung: Rafika Aditama.

Abidin, Y. (2010). Strategi membaca teori dan pembelajarannya. Bandung: RIZQI PRESS.

Arianti, D. (2015). Pendidikan Adalah Kunci Penting Berliterasi. Bandung. UPI press.

Griffin, P, et al (Eds.). (2012). Assessment and Teaching of 21st Century Skills. London: Springer.

Majid, A. (2013). Strategi Pembelajaran. Bandung: PT. Remaja Rosdakarya.

Morocco, C.C., et al. (2008). Supported Literacy for Adolescents: Transforming Teaching and Content Learning for The Twenty-First Century. San Francisco: Jossey-Bass A Wiley Imprint.

OECD. (2014). PISA 2012 Result in focus: What 15-years-olds Know and What They Can Do With What They Know.

Susanto, A. (2013). Teori Belajar dan Pembelajaran di Sekolah Dasar. Jakarta: Prenada media Group.

Susilo, S.V. \& Garnisya, G. R. (2018) 'Penerapan Model Multiliterasi Untuk Meningkatkan Kemampuan Membaca Pemahaman Siswa Sekolah Dasar', 4(2). Available at: http://jurnal.unma.ac.id/index.php/CP /article/view/1128.

Susilo, S. V. (2018) 'Refleksi Nilai-Nilai Pendidikan Ki Hadjar Dewantara Dalam Upaya Upaya Mengembalikan Jati Diri Pendidikan Indonesia', Cakrawala Pendas, 4(1), pp. 33-41. Available at: http://jurnal.unma.ac.id/index.php/CP /article/view/710. 
Waluyo, dkk. (2016). Panduan Gerakan Literasi Sekolah di Sekolah Dasar. Jakarta: Direktorat Pembinaan Sekolah Dasar.

Wiriaatmadja, R. (2006). Metode Penelitian Tindakan Kelas. Bandung: PT. Remaja Rosdakarya. 